\title{
1 A pipeline for interrogating and engineering single-subunit oligosaccharyltransferases
}

3 Thapakorn Jaroentomeechai ${ }^{1}$, Xiaolu Zheng ${ }^{1}$, Jasmine Hershewe ${ }^{2}$, Jessica C. Stark ${ }^{2}$, Michael C.

4 Jewett $^{2,3}$ and Matthew P. DeLisa ${ }^{1 *}$

5

$6{ }^{1}$ Robert Frederick Smith School of Chemical and Biomolecular Engineering, Cornell University,

7 Ithaca, NY 14853 USA

$8 \quad{ }^{2}$ Department of Chemical and Biological Engineering, Northwestern University, Evanston, IL 60208,

9 USA

$10{ }^{3}$ Center for Synthetic Biology, Northwestern University, Evanston, IL 60208, USA

12 *Address correspondence to: Matthew P. DeLisa, Robert Frederick Smith School of Chemical and

13 Biomolecular Engineering, Cornell University, Ithaca, NY 14853. Tel: 607-254-8560; Fax: 607-255-

14 9166; Email: md255@cornell.edu

Running head: An oligosaccharyltransferase pipeline

\section{Abbreviations:}

NLG:

$N$-linked protein glycosylation

single-subunit oligosaccharyltransferases

IVG:

$$
\text { in vitro glycosylation }
$$

LLOs:

lipid-linked oligosaccharides 


\section{Abstract}

2 Asparagine-linked ( $N$-linked) protein glycosylation is one of the most abundant types of post-

3 translational modification, occurring in all domains of life. The central enzyme in $N$-linked

4 glycosylation is the oligosaccharyltransferase (OST), which catalyzes the covalent attachment of

5 preassembled glycans to specific asparagine residues in target proteins. Whereas in higher

6 eukaryotes the OST is comprised of eight different membrane proteins of which the catalytic subunit

7 is STT3, in kinetoplastids and prokaryotes the OST is a monomeric enzyme bearing homology to

8 STT3. Given their relative simplicity, these single-subunit OSTs (ssOSTs) have emerged as

9 important targets for mechanistic dissection of poorly understood aspects of $\mathrm{N}$-glycosylation and at

10 the same time hold great potential for the biosynthesis of custom glycoproteins. To take advantage

11 of this utility, this chapter describes a multipronged approach for studying and engineering ssOSTs

12 that integrates in vivo screening technology with in vitro characterization methods, thereby creating

13 a versatile and readily-adaptable pipeline for virtually any SSOST of interest.

15 Keywords: asparagine-linked ( $N$-linked) protein glycosylation, bacterial glycoengineering, cell-free

16 glycosylation, cell-free protein synthesis, directed evolution, enzyme engineering, nanodisc

17 technology, post-translational modification

\section{Introduction}

20 Protein glycosylation is the attachment of glycans (mono-, oligo-, or polysaccharide) to specific amino

21 acid residues in proteins, most commonly asparagine $(N$-linked $)$ or serine and threonine $(O$-linked $)$

22 residues. Roughly three-quarters of eukaryotic proteins and more than half of prokaryotic proteins

23 are glycosylated (Dell, Galadari, Sastre, \& Hitchen, 2010). Glycosylation adds an additional

24 information layer to recipient proteins, modulating their folding and stability, receptor binding,

25 enzymatic activity, and/or localization (Varki, 1993). Many glycoproteins reside on the cell surface

26 where they influence myriad biological processes such as development (Haltiwanger \& Lowe, 2004), 
1 innate and adaptive immunity (Daniels, Hogquist, \& Jameson, 2002; Rudd, Elliott, Cresswell,

2 Wilson, \& Dwek, 2001), and host-microbe interactions in the gut (Tytgat \& de Vos, 2016).

3 Glycosylation also feature prominently in disease. For example, tumor cells commonly express

4 glycans at atypical levels or with altered structural attributes (Lau \& Dennis, 2008; Pinho \& Reis,

5 2015) while many pathogens make use of glycans during invasion of host tissue (Benz \& Schmidt,

6 2002; Valguarnera, Kinsella, \& Feldman, 2016). Glycosylation is also vitally important to the

7 development of many protein biologics, and has been harnessed for enhancing therapeutic

8 properties such as half-life extension (Elliott et al., 2003; Flintegaard et al., 2010; Ilyushin et al.,

9 2013; Lindhout et al., 2011), antibody-mediated cytotoxicity (Li et al., 2017; Lin et al., 2015), and

10 immunogenicity (Lipinski et al., 2013; Sadoulet et al., 2007; Wacker et al., 2014). Yet despite the

11 importance of glycosylation, forward progress in the field has lagged due in large part to a lack of

12 tools for rapid and systematic characterization of the enzymes involved in the glycosylation process,

13 in particular the oligosaccharyltransferase (OST). The net result is that glycans and their

14 corresponding glycoconjugates remain one of the most important but least understood class of

15 molecules in all of biology and medicine.

16 Eukaryotic and prokaryotic $N$-linked protein glycosylation (NLG) systems share many

17 mechanistic features (Weerapana \& Imperiali, 2006). Both involve enzymatic synthesis of a lipid-

18 linked oligosaccharide (LLO) donor and transfer of the preassembled glycan from the lipid to the

19 sequon of a target protein in a reaction that is catalyzed by an OST. In higher eukaryotes, the OST

20 is comprised of eight different membrane proteins of which the catalytic subunit is STT3 (Yan \&

21 Lennarz, 2002), whereas in kinetoplastids (i.e., Trypanosoma brucei and Leishmania major) and

22 prokaryotes the OST is a monomeric enzyme bearing homology to STT3 (Lizak, Gerber, Numao,

23 Aebi, \& Locher, 2011; Matsumoto et al., 2013; Nasab, Schulz, Gamarro, Parodi, \& Aebi, 2008).

24 Amongst this latter group, the OST from the bacterium Campylobacter jejuni, named PgIB

25 (hereafter $\mathrm{CjPg} \mid \mathrm{B}$ ), has been most extensively studied and thus serves as the archetype for single-

26 subunit OSTs (ssOSTs). Naturally, CjPgIB is part of a bona fide NLG pathway in C. jejuni where it 
catalyzes the en bloc transfer of preassembled heptasaccharide glycans from undecaprenol pyrophosphate (Und-PP) to protein substrates that bear the acceptor sequon D/E-X $\mathrm{C}_{-1}-\mathrm{N}-\mathrm{X}_{+1}-\mathrm{S} / \mathrm{T}$

3 (where $X_{-1}$ and $X_{+1} \neq P$ ) (for a review, see ref. (Nothaft \& Szymanski, 2010)). Shortly after its

4 discovery, the entire C. jejuni NLG pathway including CjPgIB was functionally reconstituted in

5 Escherichia coli (Wacker et al., 2002). Using this recombinant platform, it was demonstrated that

6 PgIB can transfer a wide array of structurally diverse oligosaccharides (Feldman et al.; Valderrama-

7 Rincon et al.), highlighting its potential value in glycoengineering applications. However, while

8 specificity towards the glycan donor is relaxed, CjPgIB recognizes a more stringent protein acceptor

9 site compared to the $\mathrm{N}-\mathrm{X}-\mathrm{S} / \mathrm{T}(\mathrm{X} \neq \mathrm{P})$ sequon recognized by eukaryotic OSTs (Kowarik, Young, et

10 al., 2006). Specifically, CjPgIB requires an acidic residue in the -2 position of the sequon, thereby

11 restricting bacterial NLG to a narrow set of polypeptides. To better understand this so-called "minus

12 two rule" and whether it was conserved across Gram-negative bacterial species, we systematically

13 characterized the acceptor site specificities of a diverse collection of more than 20 PgIB homologs

14 using an ectopic trans-complementation strategy in the same recombinant $E$. coli platform

15 described above. Our metagenomic screening revealed that the majority of bacterial ssOSTs

16 preferred a negatively charged residue in the -2 position, akin to CjPglB; however, five ssOSTs

17 were identified that recognized a broader range of acceptor sites (Ollis et al., 2015).

Directed evolution is emerging as an alternative strategy for shedding additional light on the sequence determinants governing the specificity of bacterial ssOSTs and for identifying unique ssOSTs with desirable substrate (i.e., glycan, protein acceptor) specificity with the potential to

21 overcome some of the limitations of this system. The success of such directed evolution efforts

22 hinges critically on the availability of high-throughput reporter assays that generate a genotype-

23 glycophenotype linkage. To date, a handful of genetic screens for NLG have been described for this

24 purpose, all of which combine glycoengineered E. coli carrying the complete protein glycosylation

25 (pgl) locus of $C$. jejuni (Wacker et al., 2002) with a functional readout of glycosylation activity.

26 Notable examples include: ELISA-based detection of periplasmic glycoproteins (Ihssen et al., 2012; 
1 Pandhal et al., 2013), glycophage display (Celik, Fisher, Guarino, Mansell, \& DeLisa, 2010; Durr,

2 Nothaft, Lizak, Glockshuber, \& Aebi, 2010), cell surface display of glycoconjugates (Fisher et al.,

3 2011; Mally et al., 2013; Valderrama-Rincon et al., 2012), and glycosylation of secreted $\underline{N}$-linked

4 acceptor proteins (glycoSNAP) (Ollis, Zhang, Fisher, \& DeLisa, 2014). Using this latter system, we

5 successfully isolated CjPgIB variants recognizing the minimal $\mathrm{N}-\mathrm{X}-\mathrm{S} / \mathrm{T}$ sequon used by eukaryotic

6 OSTs (Ollis et al., 2014). One of the more interesting variants was capable of modifying a native

7 sequon in the eukaryotic protein RNase A, an acceptor protein that had previously been

8 inaccessible to the wild-type CjPglB enzyme.

$9 \quad$ Here, we describe an integrated platform for studying and engineering ssOSTs that

10 combines in vivo screening using glycoSNAP with state-of-the-art in vitro characterization methods,

11 thereby creating a versatile and readily-adaptable pipeline for virtually any ssOST of interest (Fig.

12 1). The first step in the pipeline involves in vivo screening using glycoSNAP, whereby modified

13 colony blotting on nitrocellulose membranes is used to create a genotype-glycophenotype linkage

14 (Fig. 2). While our efforts to date have focused on identifying variants of bacterial ssOSTs that are

15 able to modify non-canonical acceptor sequences, the assay could easily be extended to screen

16 libraries of bacterial or non-bacterial ssOSTs (Matsumoto et al., 2013; Nasab et al., 2008) for

17 variants that overcome other system limitations such as low efficiency with certain non-native

18 glycan substrates (Ihssen et al., 2015). After screening, the identified SSOST candidates are

19 subjected to further activity interrogation using an in vitro glycosylation (IVG) assay. The advantage

20 of IVG is that it provides a platform where the glycosylation components can be easily decoupled

21 and carefully investigated, in contrast to the more difficult to control NLG pathways in living cells. To

22 facilitate rapid activity screening, candidate ssOSTs are prepared using a novel cell-free protein

23 synthesis (CFPS)-nanodisc system that we recently developed (Schoborg et al., 2017). This latter

24 system is capable of producing multiple active sSOSTs within a day, enabling facile and high-

25 throughput activity screening of ssOSTs. Alternatively, sSOST candidates can be prepared using an

26 economical alternative involving extraction of crude membrane extracts from $E$. coli cells expressing 
1 the ssOST of interest (Jervis et al., 2010). Finally, we provide optimized protocols for purification of

2 active sSOSTs in high yield. Purified sSOSTs are valuable reagents for studying enzyme activity

3 and mechanism under the most well-defined conditions. In addition, the purified enzyme is a

4 prerequisite for structural interrogation using methods such as in-solution protein NMR (Huang,

5 Mohanty, \& Banerjee, 2010) and X-ray crystallography (Lizak et al., 2011; Matsumoto et al., 2013).

6 Taken together, our comprehensive protocols provide a robust and modular pipeline for developing

7 a suite of flexible, single-subunit $N$-glycosylation biocatalysts and growing the glycoengineering

8 armament.

9

\section{Materials}

\subsection{Media}

1. Luria-Bertani (LB) broth: $1.0 \%(\mathrm{w} / \mathrm{v})$ tryptone, $0.5 \%(\mathrm{w} / \mathrm{v})$ yeast extract, $0.5 \%(\mathrm{w} / \mathrm{v}) \mathrm{NaCl}$, autoclave sterile.

2. LB agar: add $1.5 \%(\mathrm{w} / \mathrm{v})$ agar to LB prepared as above. Aliquot $30 \mathrm{~mL}$ of LB agar per $150 \mathrm{~mm}$ petri dish into a plastic conical tube. Add appropriate antibiotics and sterile $0.2 \%$ (w/v) D-glucose. Mix and pour into petri dishes. For induction plates, omit glucose and add sterile $0.2 \%(w / v)$ L-arabinose and $0.1 \mathrm{mM}$ isopropyl- $\beta$-D-thiogalactopyranoside (IPTG).

3. Terrific broth (TB): $1.2 \%(\mathrm{w} / \mathrm{v})$ tryptone, $2.4 \%(\mathrm{w} / \mathrm{v})$ yeast extract, $0.4 \%(\mathrm{v} / \mathrm{v})$ glycerol, $10 \%$ (v/v) phosphate buffer $\left(0.17 \mathrm{M} \mathrm{KH}_{2} \mathrm{PO}_{4}, 0.72 \mathrm{M} \mathrm{K}_{2} \mathrm{HPO}_{4}\right)$, autoclave sterile. Autoclave phosphate buffer separately from other components and add to the broth prior use.

4. 2xYTPG broth: $1.6 \%(\mathrm{w} / \mathrm{v})$ tryptone, $1.0 \%(\mathrm{w} / \mathrm{v})$ yeast extract, $0.5 \%(\mathrm{w} / \mathrm{v}) \mathrm{NaCl}, 1.8 \%$ (w/v) glucose, $0.7 \%(\mathrm{w} / \mathrm{v}) \mathrm{K}_{2} \mathrm{HPO}_{4}, 0.3 \%(\mathrm{w} / \mathrm{v}) \mathrm{KH}_{2} \mathrm{PO}_{4}$, adjust $\mathrm{pH}$ to 7.3 with $5 \mathrm{~N} \mathrm{KOH}$ and autoclave sterile. Autoclave $40 \%(\mathrm{w} / \mathrm{v})$ glucose stock separately and add to the broth prior use.

\subsection{Media supplements}


1. Transformation and storage solution (1×TSS): supplement LB broth with $10 \%(\mathrm{w} / \mathrm{v})$ polyethylene glycol (PEG)-8000, 5\% (v/v) dimethylsulfoxide (DMSO), and $20 \mathrm{mM} \mathrm{MgSO}_{4}$; adjust $\mathrm{pH}$ to 6.5 with $\mathrm{HCl}$, and autoclave sterile.

2. Antibiotics: Ampicillin (Amp) is used at $100 \mu \mathrm{g} / \mathrm{mL}$. To make a $1,000 \times$ stock, mix $1 \mathrm{~g}$ in $10 \mathrm{~mL}$ nanopure water. Chloramphenicol (Cam) is used at $20 \mu \mathrm{g} / \mathrm{mL}$. To make a $1,000 \times$ stock, dissolve $0.2 \mathrm{~g}$ in $10 \mathrm{~mL}$ ethanol. Trimethoprim (Tp) is used at $100 \mu \mathrm{g} / \mathrm{mL}$. To make a $500 \times$ stock, dissolve $0.5 \mathrm{~g}$ in $10 \mathrm{~mL}$ DMSO. Kanamycin $(\mathrm{Km})$ is used at $50 \mathrm{mg} / \mathrm{mL}$. To make a $1,000 \times$ stock, dissolve $0.5 \mathrm{~g}$ in $10 \mathrm{~mL}$ nanopure water. All antibiotic stock is filter sterile.

3. Inducers/repressors: $20 \%(\mathrm{w} / \mathrm{v})$ L-arabinose stock, $20 \%(\mathrm{w} / \mathrm{v}) \mathrm{D}-\mathrm{glucose}$, and $0.1 \mathrm{M}$ Isopropyl $\beta$-D-1-thiogalactopyranoside (IPTG) stock. All inducer/repressor stocks are made in nanopure water and filter sterilize.

\subsection{Bacterial strains and plasmids}

\begin{tabular}{lll}
\hline Strain or Plasmid & Description & Ref
\end{tabular}

E. coli strains:

CLM24

W3110 $\Delta$ waaL - used for NLG studies and efficient

(Feldman

secretion of YebF-acceptor sequon chimeras. It is also

et al.,

used for purification, extraction, and crude membrane

extract preparation of sSOST and LLOs.

BL21 Star (DE3) Used for expression and purification of acceptor protein

targets. E. coli extract from this strain is used for high-

yield cell-free protein synthesis of ssOSTs

Plasmids:

pMAF10

wild-type C. jejuni PglB

(Feldman 
et al.,

2005)

pSN18

wild-type C. jejuni PglB with 10x-His tag for purification

(Kowarik,

Numao, et

al., 2006)

pMW07-pgl $\triangle \mathrm{B}$

C. jejuni pg/ locus with CjPgIB deletion

(Ollis et

al., 2014)

pET28a(+)-scFv13- gene encoding single-chain Fv (scFv) antibody fragment (Ollis et

R4 (N34L, with engineered glycosylation tag (GlycTag) at C-

al., 2015)

N77L) $)^{\text {DQNAT-6xHis }}$ terminus for IVG studies and 6x-His tag for purification

pTrc-YebF ${ }^{4 \times A Q N A T}$ and gene encoding secreted YebF acceptor protein with

(Ollis et

pTrc-YebF ${ }^{1 \times A Q N A T-}$

3XAQNAV

pJL1-CjOST engineered GlycTag at C-terminus for IVG studies using glycoSNAP assay

wild-type C. jejuni PgIB in CFPS-compatible plasmid al., 2014)

(Schoborg

et al.,

2017)

\subsection{GlycoSNAP assay}

1. Table-top centrifuge.

2. $0.45 \mu \mathrm{m}, 142 \mathrm{~mm}$ Whatman cellulose nitrate filter membranes (VWR).

3. Nitrocellulose hybridization and transfer membranes (GE).

4. Sterile $1 \times$ phosphate buffered saline (PBS): $137 \mathrm{mM} \mathrm{NaCl}, 2.7 \mathrm{mM} \mathrm{KCl}, 10 \mathrm{mM}$ $\mathrm{Na}_{2} \mathrm{HPO}_{4}$, and $1.8 \mathrm{mM} \mathrm{KH}_{2} \mathrm{PO}_{4}$ in nanopure water, autoclave sterile.

5. $30^{\circ} \mathrm{C}$ and $37^{\circ} \mathrm{C}$ stationary incubators.

6. Metal tweezers.

7. Flat-bottomed dish to fit membrane. 
8. $20 \%(w / v)$ trichloroacetic acid (TCA) in nanopure water.

Caution! Always wear gloves when handling TCA since it can cause severe burns. Using nitrile gloves and handling TCA in fume hood are recommended.

9. Laemmli sample buffer: (for a $2 \times$ stock), mix $4 \mathrm{~mL}$ of $10 \%(\mathrm{w} / \mathrm{v})$ sodium dodecyl sulfate (SDS), $2 \mathrm{~mL}$ of glycerol, $1.2 \mathrm{~mL}$ of $1 \mathrm{M} \mathrm{Tris}-\mathrm{HCl}, \mathrm{pH} 6.8$, and $2.8 \mathrm{~mL}$ of nanopure water. Add $0.5 \mathrm{mg}$ of bromophenol blue. Add $\beta$-mercaptoethanol to a final concentration of $5 \%$ (v/v).

\subsection{Preparation of ssOSTs by CFPS}

\subsubsection{S30 extract preparation}

1. Avestin EmulsiFlex B15 (volumes $<15 \mathrm{~mL}$ ) or $\mathrm{C} 3(>15 \mathrm{~mL})$ high-pressure homogenizer.

2. High-speed centrifuge and rotor capable of spinning at 30,000xg.

3. $1 \times \mathrm{S} 30$ extract buffer: $10 \mathrm{mM}$ TrisOAc, $14 \mathrm{mM} \mathrm{Mg}(\mathrm{OAc})_{2}, 60 \mathrm{mM} \mathrm{KOAc}, \mathrm{pH} 8.2$, filter sterile.

4. Sterile $50 \mathrm{~mL}$ falcon tube, $15 \mathrm{~mL}$ disposable conical tubes, and $1.5 \mathrm{~mL}$ microcentrifuge tube.

5. Aluminum foil.

6. Liquid nitrogen and dewar.

\subsubsection{Producing sSOST in CFPS supplemented with POPC-nanodiscs}

1. $\mathrm{S} 30$ extract

2. Stock solutions: All stock solution is dissolved in nanopure water and filter sterile. The aliquots of the stocks are flash-frozen and stored at $-80^{\circ} \mathrm{C}$. Keep working stocks at $-20^{\circ} \mathrm{C}$ for several months.

a. $15 \times$ salt solution (SS): $180 \mathrm{mM} \mathrm{Mg}(\mathrm{Glu})_{2}, 150 \mathrm{mM} \mathrm{NH}_{4}(\mathrm{Glu})$, and $1.950 \mathrm{M} \mathrm{K}(\mathrm{Glu})_{2}$.

b. $15 \times$ master mix (MM) stock: $18 \mathrm{mM}$ adenosine triphosphate (ATP), $12.75 \mathrm{mM}$ guanosine triphosphate (GTP), $12.75 \mathrm{mM}$ uridine triphosphate (UTP), $12.75 \mathrm{mM}$ 
cytidine triphosphate (CTP), $0.51 \mathrm{mg} / \mathrm{mL}$ folinic acid, and $2.559 \mathrm{mg} / \mathrm{mL}$ E. coli tRNA (Roche).

c. $15 \times$ reagent mix $(\mathrm{RM})$ stock: $50 \mathrm{mM}$ amino acids mix, $1 \mathrm{M}$ phosphoenolpyruvate (PEP, Roche), 100 mM nicotinamide adenine dinucleotide (NAD), 50 mM coenzymeA (CoA), $1 \mathrm{M}$ oxalic acid, $250 \mathrm{mM}$ putrescine, $250 \mathrm{mM}$ spermidine, and $1 \mathrm{M}$ HEPES.

3. Purified 1-palmitoyl-2-oleoyl-sn-glycero-3-phosphocholine (POPC) nanodiscs at 15 $\mathrm{mg} / \mathrm{mL}$ stock concentration, prepared according to the standard protocol (Bayburt, Grinkova , \& Sligar, 2002).

4. Nuclease-free water.

5. Sterile $1.5 \mathrm{~mL}$ microcentrifuge tube.

\subsection{Protein purification and crude membrane extracts containing ssOST or LLOs}

1. Buffer A Resuspend buffer: $50 \mathrm{mM}$ HEPES, $250 \mathrm{mM} \mathrm{NaCl}, \mathrm{pH}$ 7.5, filter sterile with 0.2 $\mu \mathrm{m}$ bottle-top filter.

2. Pierce ${ }^{\mathrm{TM}}$ Protease Inhibitor Tablets, EDTA-free.

3. RNase-Free DNase I from EpiCentre.

4. Avestin EmulsiFlex C5 homogenizer.

5. Buffer B: buffer A supplied with 10\% (v/v) Glycerol and 1\% (w/v) n-Dodecyl $\beta-D-$ maltoside (DDM), at pH 7.5 and filter sterile.

6. Centrifuge and ultracentrifuge with rotor capable of spinning at $100,000 \mathrm{xg}$.

7. Potter-Elvehjem tissue homogenizer.

8. Ni-NTA affinity resin.

9. Gravity column for affinity purification.

10. Nickel affinity purification buffers:

For preparing ssOST:

Buffer C: 1 M Imidazole in buffer B.
For preparing scFv13-R4:

Buffer P: $1 \mathrm{M}$ Imidazole in buffer A. 
Buffer D: $20 \mathrm{mM}$ Imidazole in buffer B. Buffer Q: $10 \mathrm{mM}$ Imidazole in buffer A.

Buffer E: 60 mM Imidazole in buffer B. Buffer R: 60 mM Imidazole in buffer A.

Buffer F: 250 mM Imidazole in buffer B. Buffer S: 250 mM Imidazole in buffer A.

11. ÄKTA fast protein purification (FPLC) system with SuperDex-200 size exclusion chromatography column.

12. Size exclusion buffers using with ÄKTA system:

For preparing ssOST:

Buffer G: 50 mM HEPES, 100 mM

$\mathrm{NaCl}, 5 \%(\mathrm{v} / \mathrm{v})$ glycerol, $0.01 \%(\mathrm{w} / \mathrm{v})$

DDM, pH 7.5, filter sterile and degas for
For preparing scFv13-R4:

Buffer T: 50 mM HEPES, 100 mM NaCl, 1 mM EDTA, pH 7.5, filter sterile and degas for $5 \mathrm{~min}$.

$5 \min$.

13. 3K MWCO protein concentrator column.

14. BioRad Bradford protein concentration assay.

15. BioRad RC DC ${ }^{\mathrm{TM}}$ (reducing agent and detergent compatible) protein concentration assay.

1. Lyophilizer.

2. $30 \mathrm{~mL}$ PTFE-conical tube.

3. Extracting solution: 10:20:3 (v/v/v) chloroform:methanol:water. Measure and mix all solvent in glassware since chloroform will dissolve plastic. Store the solution in a capped bottle at all time to prevent concentration change due to evaporation of chloroform and methanol. since chloroform is toxic.

4. Clean metal spatula. 
5. $15 \mathrm{~mL}$ clean glass vial.

6. Vacuum concentrator machine that withstand organic solvent.

\subsection{IVG reaction}

1. Sterile $1.5 \mathrm{~mL}$ microcentrifuge tube.

2. 10× IVG buffer stock: $100 \mathrm{mM}$ HEPES, $100 \mathrm{mM} \mathrm{MnCl}_{2}, 1 \%(\mathrm{w} / \mathrm{v}) \mathrm{DDM}, \mathrm{pH} 7.5$ in nanopure water and filter sterile.

3. Sterile nanopure water.

4. $30^{\circ} \mathrm{C}$ stationary water bath.

\subsection{Lectin blot and Western blot analysis of glycosylation products}

1. Standard apparatus for SDS-PAGE and immunoblotting analysis.

2. Immobilon-P PVDF $0.45 \mu \mathrm{m}$ membrane.

3. Tris-buffered saline (TBS): dissolve $80.0 \mathrm{~g}$ of $\mathrm{NaCl}, 20.0 \mathrm{~g}$ of $\mathrm{KCl}$, and $30.0 \mathrm{~g}$ of Tris base in $800 \mathrm{~mL}$ of nanopure water, bring volume to $1 \mathrm{~L}$ and autoclave.

4. Tris-buffered saline, $0.05 \%$ Tween-20 (TBST): Add $100 \mathrm{~mL}$ of $10 \times$ TBS to $900 \mathrm{~mL}$ of nanopure water. Add $500 \mu \mathrm{L}$ Tween-20.

5. Albumin from bovine serum (BSA): $5 \%(\mathrm{w} / \mathrm{v})$ in TBST for blocking solution, $3 \%(\mathrm{w} / \mathrm{v})$ in TBST for lectin blotting. When using lectin, BSA/TBST is a preferred blocking solution than milk/TBST to prevent interaction between lectin and milk oligosaccharides.

6. Non-fat dry milk Nestle ${ }^{\circledR}: 5 \%(w / v)$ in TBST for blocking solution for all other antibodies.

7. Anti-6xHis Tag antibody peroxidase conjugate (His-HRP, from Abcam): $0.5 \mu \mathrm{g} / \mathrm{mL}$ in $5 \%$ milk/TBST.

8. Soybean agglutinin peroxidase conjugate (SBA-HRP): $0.5 \mu \mathrm{g} / \mathrm{mL}$ in $1 \%$ BSA/TBST (or other lectin or antibody specific for the glycan of choice).

9. Rabbit serum containing anti-C.jejuni heptasaccharide glycan antibody (HR6P-Rabbit) [Note 1]: $0.5 \mu \mathrm{g} / \mathrm{mL}$ in $5 \%$ milk/TBST. 
10. Goat Anti-Rabbit IgG H\&L peroxidase conjugate (Rabbit-HRP, from Abcam): $0.05 \mu \mathrm{g} / \mathrm{mL}$ in $5 \%$ milk/TBST.

11. BioRad Clarity ${ }^{\mathrm{TM}}$ Western ECL Substrate.

12. \% Coomassie Brilliant Blue membrane stain solution: dissolve $0.1 \mathrm{~g}$ of Coomassie Blue $\mathrm{R} 250$ in $50 \mathrm{~mL}$ of methanol $(\mathrm{MeOH}), 7 \mathrm{~mL}$ of acetic acid, and $43 \mathrm{~mL}$ of nanopure water. Stain can be saved and reused multiple times.

13. Destain solution: $50 \% \mathrm{MeOH}$ in nanopure water. Discard destain following hazardous waste protocols.

14. BioRad ChemiDoc ${ }^{\mathrm{TM}} \mathrm{XRS}+$ System.

\section{Methods}

\subsection{GlycoSNAP assay}

Days 0-1 Transformation of glycocompetent E. coli for library screening

1. Inoculate $5 \mathrm{~mL}$ LB supplemented with $0.2 \%$ D-glucose and antibiotics as needed with a single colony of the strain to be transformed. Grow overnight at $37^{\circ} \mathrm{C}$.

2. Subculture 1:100 from the overnight culture into a fresh $5-\mathrm{mL}$ volume of the same medium. Grow until culture density $\left(\mathrm{OD}_{600}\right)$ reaches $0.4-0.5$.

3. Harvest $5 \times 1 \mathrm{~mL}$ into Eppendorf tubes [Note 2]. Chill on ice for $5 \mathrm{~min}$. Pellet cells at $4^{\circ} \mathrm{C}$ in a tabletop centrifuge. Discard supernatant. Resuspend cell pellets in $100 \mu \mathrm{L}$ of ice-cold $1 \times$ TSS.

4. Add $50-200$ ng of library plasmid miniprep to the prepared cells. Incubate on ice for 30 min. Heat shock 90 s at $42{ }^{\circ} \mathrm{C}$. Immediately add $500 \mu \mathrm{L}$ of LB to rescue cells. Incubate for $1 \mathrm{~h}$ at $37^{\circ} \mathrm{C}$ with aeration. Pour LB agar plates as needed in preparation for the next step. 
5. Plate at least $100 \mu \mathrm{L}$ of cells and spread evenly using a spreader or sterile beads. A plating with optimal cell density for screening should yield about 2,500 colonies on a 150-mm plate. Incubate plates at $37^{\circ} \mathrm{C}$ overnight.

\section{Days 2-3 GlycoSNAP Assay}

6. Trim one cellulose nitrate filter circle and one piece of nitrocellulose membrane to fit a $150-\mathrm{mm}$ plate (one set for each transformation plate to be screened). Cut two notches on both filter and membrane to assist in later alignment.

7. Pre-wet the nitrocellulose membrane in $1 \times$ PBS, keeping the matte side up, and place onto a fresh induction plate. Cover with lid to prevent drying in between steps.

8. Replicate colonies from transformation plate by gently placing the cut filter membrane directly onto the plate to avoid air bubbles. The side in contact with the colonies should be the side that was not in contact with the nitrocellulose when stacked to cut.

9. Using sterilized metal tweezers, carefully peel up the colony-containing membrane and place colony-side-up onto the nitrocellulose membrane on the induction plate. Ideally, match notches on the filter and nitrocellulose membrane.

10. Incubate plates right-side-up at $30^{\circ} \mathrm{C}$ overnight $(16-18 \mathrm{~h})$.

11. The next day, use tweezers to remove the colony-containing membrane and transfer it onto a fresh LB agar plate. Save at $4^{\circ} \mathrm{C}$. Transfer the nitrocellulose membrane into a dish of $1 \times$ TBS. Shake at room temperature about $10 \mathrm{~min}$ to rinse [Note 3].

12. Block membrane for $1 \mathrm{~h}$ in $5 \%$ BSA/TBST blocking solution.

13. Incubate for $1 \mathrm{~h}$ with SBA-HRP solution. $30 \mathrm{~mL}$ of solution is sufficient to cover the 140-mm membrane circle.

14. Wash $4 \times$ with TBST, incubating each wash at least 10 min with shaking.

15. Develop blot. 
16. If desired, the blot can be stripped with standard Western blot stripping buffer and reprobed using antibodies specific for the secreted target (anti-His for the C-terminal 6xHis tag fused to the YebF construct) and/or the membrane can be stained with a general protein stain such as Coomassie blue.

\section{Days 3-5 Confirmation of positive hits}

17. Pick individual colonies identified as positive hits and restreak on LB agar plates containing the appropriate antibiotics. Incubate at $37^{\circ} \mathrm{C}$ overnight.

18. Inoculate a single colony into $5 \mathrm{~mL}$ of LB supplemented with $0.2 \%$ D-glucose and appropriate antibiotics for each hit to be tested and grow overnight at $37^{\circ} \mathrm{C}$. A control such as a strain expressing the wild-type C. jejuni pgl locus and YebF DQNAT should be included for comparison.

19. The next day, subculture the overnight cultures $1: 100$ in $5 \mathrm{~mL}$ of LB supplemented with the appropriate antibiotics and grow at $37^{\circ} \mathrm{C}$ to an $\mathrm{OD}_{600} \sim 0.6$. Induce with 100 $\mu \mathrm{M}$ IPTG and $0.2 \%$ L-arabinose. Incubate at $30^{\circ} \mathrm{C}$ overnight.

20. The next day, harvest $1 \mathrm{~mL}$ of each culture and pellet cells $5 \mathrm{~min}$ at $4^{\circ} \mathrm{C}$. Determine protein concentration in the supernatants using a Bradford assay. Harvest volumes with equal protein concentrations and precipitate protein by addition of an equal volume of ice-cold $20 \%$ TCA. Vortex and incubate on ice for at least $15 \mathrm{~min}$. Pellet precipitated protein by centrifuging at $10,000 \times \mathrm{g}, 5 \mathrm{~min}$, at $4^{\circ} \mathrm{C}$. Discard supernatant. Centrifuge briefly a second time and remove any residual acid. Resuspend pellets in $25 \mu \mathrm{L}$ of $1 \mathrm{M}$ Tris- $\mathrm{HCl}, \mathrm{pH} 7.5$ then add $25 \mu \mathrm{L}$ of $2 \times$ Laemmli sample buffer. Boil $5-$ $10 \mathrm{~min}$.

21. Detect glycosylation state by standard SDS-PAGE and immunoblotting (see section 3.5).

22. Plasmids from true positive hits can be isolated and sequenced to identify mutations conferring activity. 


\subsection{Preparation of ssOST by CFPS}

\subsubsection{S30 extract preparation}

1. Grow E. coli strain BL21 Star (DE3) in a shake flask or fermenter to $O_{600} \sim 3$ in 2×YTPG media. Add $1 \mathrm{mM}$ IPTG at $\mathrm{OD}_{600}$ 0.6-0.8 to induce expression of T7 RNA polymerase.

2. Harvest cells by centrifugation at $5000 x g$ for 15 min at $4{ }^{\circ} \mathrm{C}$. Wash cells $3 x$ in $25 \mathrm{~mL}$

Day 3 preparing extract equipment in contact with lysate should be pre-equilibrated to $4^{\circ} \mathrm{C}$.

3. Remove cell pellet from $-80^{\circ} \mathrm{C}$ and add $1 \mathrm{~mL}$ of $\mathrm{S} 30$ buffer per $1 \mathrm{~g}$ of wet cell mass. lysis is the key step in extract preparation and could be alternatively performed using sonication (Kwon \& Jewett, 2015).

5. Centrifuge lysate at $30,000 \times \mathrm{g}$ for $30 \mathrm{~min}$ at $4^{\circ} \mathrm{C}$ to remove cell debris.

6. Immediately pipette the supernatant into new centrifuge tubes and centrifuge again at the same setting.

7. Immediately pipette supernatant into $1.5-\mathrm{mL}$ microcentrifuge tubes. $37^{\circ} \mathrm{C}$ in a shaker $(\sim 120-250 \mathrm{rpm})$ for $60 \mathrm{~min}$. 
9. Clarification: centrifuge at $15,000 \times \mathrm{g}$ for $15 \mathrm{~min}$ at $4^{\circ} \mathrm{C}$. Immediately pipette the supernatant into $15 \mathrm{~mL}$ disposable conical tubes and place on ice.

10. Immediately make $50 \mu \mathrm{L}$ aliquot and $1-2 \mathrm{~mL}$ volume stocks of the cell extract. Flash freeze in liquid nitrogen and store at $-80^{\circ} \mathrm{C}$.

11. Perform a Bradford assay to measure total protein concentration (usually $\sim 40 \mathrm{~g} / \mathrm{L}$ ). S30 extract performance is maintained for approximately 3 freeze-thaw cycles.

\subsubsection{Producing ssOST in CFPS supplied with POPC-nanodiscs}

1. Calculate the appropriate volumes of each reagent according to total number of reactions. Ensure that all components are at the concentrations listed.

2. Thaw all the reagents on ice. Set up microcentrifuge tubes on ice, one for each cellfree reaction and one for reaction premix.

Swartz, 2004):

\begin{tabular}{ll}
\hline CFPS components & $\begin{array}{l}\text { Volume per 1 reaction } \\
(\mu \mathrm{L})\end{array}$ \\
\hline $15 x \mathrm{SS}$ & 1 \\
$15 x \mathrm{MM}$ & 1 \\
$15 x \mathrm{RM}$ & 1 \\
pJL1 plasmid encoding ssOST & $200 \mathrm{ng}$ \\
S30 extract & 4 \\
$15 \mathrm{mg} / \mathrm{mL}$ POPC nanodiscs & 1 \\
\hline Nuclease-freee water & Bring final volume to $15 \mu \mathrm{L}$ \\
\hline
\end{tabular}

a. To make a premix, combine the appropriate amounts of $15 \times \mathrm{SS}, 15 \times \mathrm{MM}$, $15 \times \mathrm{RM}$, plasmid and nuclease-free water in reaction premix tube. Vortex and quickly spin down the tube [Note 4]. 
b. Then add the appropriate amounts of POPC nanodiscs and S30 extract.

c. Gently pipette the mixture up and down to thoroughly mix all components, but make sure to minimize bubble formation.

4. Aliquot $15 \mu \mathrm{L}$ premix into individual microcentrifuge tube.

5. Briefly centrifuge CFPS-reaction tubes to ensure all liquid is held at the bottom of the tube.

6. Incubate reaction at $30^{\circ} \mathrm{C}$ for $6 \mathrm{~h}$ in a stationary water bath. The CFPS reaction containing SSOST in nanodisc can be loaded directly into IVG reaction for rapid glycosylation screening.

\subsection{Preparation of purified and crude membrane extract glycosylation components}

\subsubsection{Preparation of crude membrane extract or purified sSOST enzyme}

Days 0-1

1. Grow E. coli strain CLM24 carrying pSN18 plasmid in $50 \mathrm{~mL}$ LB supplied with ampicillin and $0.2 \%$ D-glucose overnight at $37^{\circ} \mathrm{C}$.

2. Subculture 1:20 from the overnight culture into a fresh $1.0 \mathrm{~L}$ TB supplied with ampicillin. Grow with shaking at $220 \mathrm{rpm}$ until $\mathrm{OD}_{600}$ reaches $0.4-0.5$.

3. Adjust incubation temperature to $16^{\circ} \mathrm{C}$ and leave the culture with shaking for an hour.

4. Induce protein expression with $0.02 \% \mathrm{~L}$-arabinose. Incubate at $16^{\circ} \mathrm{C}$ overnight.

Day 2 prepare membrane extract containing active CjOST

5. The next day, harvest cell by centrifugation at $8,000 \times \mathrm{g}$ for $10 \mathrm{~min}$ at $4^{\circ} \mathrm{C}$. Wash cell pellet by resuspending with $200 \mathrm{~mL}$ buffer A and centrifuge again at the same setting. Discard supernatant. Collect pellet and determine wet cell mass. Pellet can be saved in $-80^{\circ} \mathrm{C}$ fridge for a month or used directly.

6. Resuspend cell pellet using $10 \mathrm{~mL}$ buffer A per $1 \mathrm{~g}$ wet cell mass. Add EDTA-free protease inhibitor to prevent protein degradation. Add DNAse to reduce sample viscosity. Use standard manufacturer's protocol. 
7. Pre-equilibrate Avestin homogenizer with ice-cold buffer A. Disrupt cells using Avestin C5 EmulsiFlex homogenizer at 17,000 psi for 3 passes.

8. Centrifuge lysate at $30,000 \times \mathrm{g}$ for $30 \mathrm{~min}$ at $4^{\circ} \mathrm{C}$ to remove cell debris.

9. Collect and ultracentrifuge supernatant at $100,000 \times \mathrm{g}$ for $2 \mathrm{~h}$ at $4^{\circ} \mathrm{C}$ to isolate membrane fraction.

10. Collect pellet containing membrane fraction and CjOST. Resuspend pellet in $20 \mathrm{~mL}$ buffer B using Potter-Elvehjem tissue homogenizer. Make sure to fully resuspend the pellet [Note 5]. Transfer homogenized sample into sterile $50 \mathrm{~mL}$ conical tube. Add protease inhibitor cocktail into sample and incubate with shaking (120 rpm) at room temperature for an hour. The DDM detergent in buffer B will extract and solubilize CjOST from bacterial membrane.

11. Ultracentrifuge sample at $100,000 \times \mathrm{g}$ for an hour at $4^{\circ} \mathrm{C}$. The supernatant now contains detergent-solubilized CjOST enzyme.

Alternatively: To prepare crude membrane extract containing active CjOST, centrifuge sample at $20,000 \times \mathrm{g}$ for an hour at $4^{\circ} \mathrm{C}$. Collect and immediately add protease inhibitor into supernatant after centrifugation. The crude membrane extract is active at $4^{\circ} \mathrm{C}$ for one week. We have demonstrated the use of this method to prepare several active sSOSTs that can modifty targeted protein acceptor. In addition, crude membrane extract containing active LLOs can be prepared in a similar method [Note 6].

12. Add $0.4 \mathrm{~mL}$ buffer $\mathrm{C}$ into supernatant to adjust imidazole concentration to $20 \mathrm{mM}$. 13. Equilibrate $0.5 \mathrm{~mL} \mathrm{Ni-NTA}$ resin by washing with ice-cold buffer $\mathrm{D}$ at 5 times bed volume. Add pre-equilibrated Ni-NTA resin into supernatant, incubate with rolling overnight at $4^{\circ} \mathrm{C}$.

Day 3 purification by affinity and size exclusion chromatography (SEC) 
Keep sample on ice at all times unless noted otherwise. All equipment in contact with sample should be pre-equilibrated to $4^{\circ} \mathrm{C}$.

14. Load sample into clean gravity column at the flowrate of $0.5 \mathrm{~mL} / \mathrm{min}$.

15. Wash resin with 5 bed volumes of buffer $D$, followed by 5 bed volumes of buffer $E$. Then elude protein with 7 bed volumes of buffer $F$. Keep all the fractions for analysis by Coomasie blue.

16. Pre-equilibrate SuperDex-200 SEC column connecting ÄKTA-FPLC system with icecold buffer G. Load eluent fraction into sample loop. Inject sample through SEC column. Collect and combine fractions with size corresponding to CjOST (84 kDa) together.

17. Concentrate protein to $1-2 \mathrm{mg} / \mathrm{mL}$ final concentration using $3 \mathrm{~K}$ MWCO protein concentrator column. Add glycerol to the sample at $20 \%(\mathrm{v} / \mathrm{v})$ concentration. Aliquot and store $\mathrm{CjOST}$ at $-80^{\circ} \mathrm{C}$ for $4-5$ months.

18. Determine protein concentration and sample purity with RC/DC assay and Coomassie blue protein stain, respectively.

\subsubsection{Purification of acceptor protein scFv13-R4(N34L, N77L) ${ }^{\text {DQNAT-6xHis }}$}

1-8 These steps are essentially the same as protocol described in section 3.2.1 above, with a few exceptions. E. coli strain BL21 Star (DE3) carrying pET28a(+)-scFv13$\mathrm{R} 4(\mathrm{~N} 34 \mathrm{~L}, \mathrm{~N} 77 \mathrm{~L})^{\text {DQNAT-6xHis }}$ plasmid is used. The inducer for $\mathrm{pET}$-based vector is IPTG at $0.1 \mathrm{mM}$ final concentration. Kanamycin antibiotic is used at $100 \mathrm{ug} / \mathrm{mL}$.

9. Adjust the imidazole concentration in the supernatant to $10 \mathrm{mM}$ Imidazole with buffer $P$.

10. Equilibrate $0.25 \mathrm{~mL}$ Ni-NTA resin by washing with ice-cold buffer $Q$ at 5 times bed volume. Add pre-equilibrated Ni-NTA resin into supernatant, incubate with rolling at room temperature for an hour. 
Keep sample on ice at all times unless noted otherwise. All equipment in contact with sample should be pre-equilibrated to $4^{\circ} \mathrm{C}$.

11. Load sample into clean gravity column at the flowrate of $0.5 \mathrm{~mL} / \mathrm{min}$.

12. Wash resin with 5 bed volumes of buffer $Q$, followed by 5 bed volumes of buffer $R$. Then elude protein with 7 bed volumes of buffer S. Keep all the fractions for analysis by Coomasie blue.

13. Pre-equilibrate SuperDex-200-SEC column connecting ÄKTA-FPLC system with icecold buffer T. Load eluent fraction into sample loop. Inject sample through SEC column. Collect and combine fractions with size corresponding to scFv13-R4 (29 kDa) together.

14. Concentrate protein to $1-2 \mathrm{mg} / \mathrm{mL}$ final concentration using $3 \mathrm{~K}$ MWCO protein concentrator column. Add glycerol to the sample at $10 \%(\mathrm{v} / \mathrm{v})$ concentration. Aliquot and store scFv13-R4 at $-80^{\circ} \mathrm{C}$ for 6 months.

15. Determine protein concentration and sample purity with Bradford assay and Coomassie blue protein stain, respectively.

3.3.3 Extraction of LLOs bearing C. jejuni glycan (adapted from (Guarino \& DeLisa, 2012))

Days $0-2$

1-5 These steps are essentially the same as protocol described in section 3.2.1, with a few exceptions. E. coli strain CLM24 carrying pMW07-pgI $\triangle \mathrm{B}$ plasmid is used. The inducer for this plasmid is $\mathrm{L}$-arabinose at $0.2 \%$ final concentration. Chloramphenicol antibiotic is used at $20 \mathrm{ug} / \mathrm{mL}$.

6. Use clean spatula to scrap cell pellet and transfer to clean $50 \mathrm{~mL}$ conical tubes. Freeze-dry cell pellets to complete dryness at $-70^{\circ} \mathrm{C}$ with lyophilizer (usually takes $\sim 2$ days).

\section{Day 4}


7. Weigh and combine lyophilisate into a sterile $30 \mathrm{~mL}$ PTFE-conical tube. Use clean spatula to break dried pellet into small fractures.

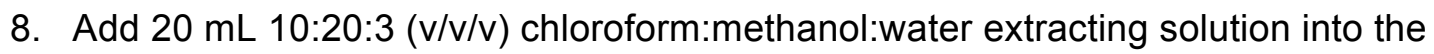
tube and incubate with shaking for $30 \mathrm{~min}$ at room temperature.

9. Centrifuge the mixture at $4000 \times \mathrm{g}$ for $15 \mathrm{~min}$ at $4^{\circ} \mathrm{C}$.

10. Transfer organic fraction (bottom layer) to a clean $15 \mathrm{~mL}$ glass vial. Remove chloroform and methanol with vacuum concentrator at room temperature (usually take $\sim 4-5 \mathrm{~h})$.

11. Place the vial into freeze-dry unit to remove residue water at $-70^{\circ} \mathrm{C}$ overnight.

Day 5

12. Lyophilisate now contains active lipid-linked oligosaccharide (CjLLOs). Weigh lyophilisate mass. Dried LLOs can be stored at $-80^{\circ} \mathrm{C}$ for 6 months.

13. Resuspend lyophilisate at $1.0 \mathrm{~mL} 1 \times$ IVG buffer per $1.0 \mathrm{mg}$ lyophilisate dried weight. The resuspension should look yellowish. Transfer the mixture to a sterile microcentrifuge tube, spin down briefly, aliquot and store soluble fraction containing active CjLLOs in $-20^{\circ} \mathrm{C}$ for up to 2 months.

\subsection{IVG setup}

Day 1

1. In a sterile 1.5-mL microcentrifuge tube, add following reagents:

a. $3 \mu \mathrm{g}$ purified antibody fragment scFv13-R4. Alternatively, N-terminal TAMRAlabelled peptide at $8.5 \mu \mathrm{M}$ can be used as an acceptor substrate [Note 7].

b. $2 \mu \mathrm{g}$ purified CjOST or $25 \mu \mathrm{L}$ crude membrane extract containing active CjOST or $25 \mu \mathrm{L}$ CFPS-nanodisc reaction containing active CjOST.

c. $5 \mu \mathrm{g}$ extracted CjLLOs.

d. $5 \mu \mathrm{L} 10 \times$ IVG buffer.

e. Bring final volume to $50 \mu \mathrm{L}$ with sterile nanopure water. 
2. In addition, it is necessary to set up control reactions to prevent fault-positive result. A typical reaction set is as follow:

\begin{tabular}{l|c|ccc}
\multicolumn{1}{c|}{ IVG components } & Sample & \multicolumn{3}{|c}{ Control } \\
\hline Protein/peptide acceptor & + & + & + & - \\
CjOST & + & + & - & + \\
CjLLOs & + & - & + & + \\
\hline
\end{tabular}

3

4. Centrifuge reaction tube at $10,000 \times \mathrm{g}$ for $15 \mathrm{~min}$ at $4^{\circ} \mathrm{C}$.

5. Collect soluble fraction. Reaction is stopped by adding Laemmli sample buffer. Keep sample at $-20^{\circ} \mathrm{C}$ for analysis by SDS-PAGE followed by immunoblotting.

\subsection{Detection of glycoprotein from in vivo and in vitro glycosylation assay.}

1. Load sample containing $50 \mu \mathrm{g}$ total protein from in vivo experiment (see section 3.1) or $0.5 \mu \mathrm{g}$ acceptor protein from IVG (see section 3.4) into SDS-polyacrylamide gels. Run protein electrophoresis at $200 \mathrm{~V}$ for $45 \mathrm{~min}$ [Note 8].

Alternatively: To detect fluorophore labelled-glycopeptide, load $10 \mu \mathrm{L}$ sample into tris-tricine polyacrylamide gel. The electrophoretic condition is at $30 \mathrm{~V}$ initial voltage for $1 \mathrm{~h}$ and then $190 \mathrm{~V}$ for $3 \mathrm{~h}$. The peptide can be visualized in-gel using any fluorescence imager.

2. Transfer protein sample onto two PVDF membrane. After transfer, wash membranes briefly with $10 \mathrm{~mL} 1 \times$ TBS buffer.

3. Incubate membranes with milk/TBST blocking solution for an hour at room temperature. BSA/TBST blocking solution is used instead for lectin blotting.

4. Wash membrane $4 \times$ with TBST, incubating each wash at least 10 min with shaking. 
5. Immunoblot one membrane with anti-His antibodies and one with glycan-specific lectin (SBA-HRP) or antibodies (hR6P) for an hour at room temperature. Then wash membrane $4 \times$ with TBST, incubating each wash at least 10 min with shaking. The anti-His and lectin SBA-HRP immunoblotting membranes are ready to develop.

6. Incubate hR6P immunoblotting membrane with anti-rabbit-HRP secondary antibody for an hour at room temperature. Then wash membrane $4 \times$ with TBST, incubating each wash at least 10 min with shaking. The anti-glycan immunoblotting membrane is ready to develop.

7. To develop immunoblotting membrane, apply $1.0 \mathrm{~mL}$ of Western ECL substrate per membrane $(9 \times 7 \mathrm{~cm})$. Incubate 5 min with shaking at room temperature. Use ChemiDoc $^{\mathrm{TM}} \mathrm{XRS}+$ System to scan chemiluminescent signal.

\section{Conclusion}

Bacterial sSOSTs are highly modular enzymes, but we have only scratched the surface on exploiting their full biocatalytic potential, including identification of mutant activities. The protocols described here provide a robust framework for (1) understanding naturally occurring ssOSTs found in the genomes of kinetoplastid and prokaryotic organisms and (2) identifying entirely novel ssOSTs with desired glycophenotypes such as specificity for target acceptor sequons and/or glycan structures. The development and application of CFPS-nanodiscs and IVG assays provides a complementary set of techniques for synthesizing ssOSTs and subsequently evaluating their activity, all within a couple of days and with minimal technical difficulty. Finally, the optimized protocol for high-yield preparation of purified sSOST enzymes will facilitate thorough biochemical and structural analysis. Overall, our pipeline is expected to extend the glycoengineering toolkit for the facile discovery of novel glycosylation biocatalysts with customized functions. 


\section{5. Notes}

1. Rabbit serum containing C.jejuni heptasaccharide glycan-specific antibody (hR6P) is made in-house and generously provided from Prof. Markus Aebi at ETH-Zürich, Switzerland.

2. Usually at least two transformations were done for each set to allow for plating of different cell densities or to ensure at least one plate with even spreading (the best one or both can be chosen to proceed with the assay).

3. This rinsing step was found to be important for cleaner blots so do not skip. For all blotting steps, it is important that the shaking evenly covers the membrane with the buffers. Insufficient shaking will result in uneven signal that will make it difficult to pick positive hits.

4. If different targeted sSOSTs will be produced in CFPS-nanodisc reaction, omit plasmid in premix and add each plasmid into individual reaction later.

5. Solubilization is a critical step in extracting active ssOST from the E. coli membrane. It is important to completely homogenize the sample and allow sufficient incubation time with DDM detergent to maximize extracting efficiency.

6. Similarly, crude membrane extract LLOs can be prepared the same way. Prepare $1 \mathrm{~L}$ TB culture with E. coli strain CLM24 carrying pMW07-pgl $\Delta \mathrm{B}$ plasmid. After protein expression and cell harvesting, disrupt cell with Emulsiflex C5 homogenizer. Ultracentrifuge supernatant to isolate membrane fraction. Following solubilization membrane fraction with DDM detergent, centrifuge resuspend at $20,000 \times \mathrm{g}$ for an hour at $4^{\circ} \mathrm{C}$. Collect supernatant containing active LLOs. The crude membrane extract is active at $4^{\circ} \mathrm{C}$ for one week.

7. We use commercial N-terminal-TAMRA-GDQNATAF peptide substrate in our assay. In-house synthesized peptide with similar sequence can also be used as a glycosylation acceptor molecule. 
8. The glycosylated protein will migrate slower in the SDS-PAGE gel due to the additional mass of the attached glycan, and on the anti-His immunoblot it will appear as a band slightly higher than the unmodified protein (if glycosylation efficiency is less than $100 \%$, two bands will be apparent). The glycosylated form can be confirmed by appearance of a corresponding band on the glycan blot.

\section{Acknowledgements}

This work was supported by the Defense Threat Reduction Agency (GRANT11631647), the David and Lucile Packard Foundation, the Dreyfus Teacher-Scholar program, and the National Science Foundation (MCB 1413563). TJ was supported by a Royal Thai Government Fellowship. JCS was supported by the National Science Foundation Graduate Research Fellowship. JH was supported by an NDSEG Fellowship.

\section{References}

Bayburt, T. H., Grinkova , Y. V., \& Sligar, S. G. (2002). Self-assembly of discoidal phospholipid bilayer nanoparticles with membrane scaffold proteins. Nano Lett, 2, 853-856.

Benz, I., \& Schmidt, M. A. (2002). Never say never again: protein glycosylation in pathogenic bacteria. Mol Microbiol, 45(2), 267-276.

Celik, E., Fisher, A. C., Guarino, C., Mansell, T. J., \& DeLisa, M. P. (2010). A filamentous phage display system for N-linked glycoproteins. Protein Sci, 19, 2006-2013. doi:10.1002/pro.472

Daniels, M. A., Hogquist, K. A., \& Jameson, S. C. (2002). Sweet ' $n$ ' sour: the impact of differential glycosylation on T cell responses. Nat Immunol, 3(10), 903-910. doi:10.1038/ni1002-903 ni1002-903 [pii]

Dell, A., Galadari, A., Sastre, F., \& Hitchen, P. (2010). Similarities and differences in the glycosylation mechanisms in prokaryotes and eukaryotes. Int J Microbiol, 2010, 148178. doi:10.1155/2010/148178 
Durr, C., Nothaft, H., Lizak, C., Glockshuber, R., \& Aebi, M. (2010). The Escherichia coli glycophage display system. Glycobiology, 20(11), 1366-1372. doi:cwq102 [pii] 10.1093/glycob/cwq102

Elliott, S., Lorenzini, T., Asher, S., Aoki, K., Brankow, D., Buck, L., . . Egrie, J. (2003). Enhancement of therapeutic protein in vivo activities through glycoengineering. Nat Biotechnol, 21(4), 414-421.

Feldman, M. F., Wacker, M., Hernandez, M., Hitchen, P. G., Marolda, C. L., Kowarik, M., . . Aebi, M. (2005). Engineering N-linked protein glycosylation with diverse $\mathrm{O}$ antigen lipopolysaccharide structures in Escherichia coli. Proc Natl Acad Sci U S A, 102(8), 30163021. doi:0500044102 [pii] 10.1073/pnas.0500044102

Fisher, A. C., Haitjema, C. H., Guarino, C., Celik, E., Endicott, C. E., Reading, C. A., . . DeLisa, M. P. (2011). Production of secretory and extracellular N-linked glycoproteins in Escherichia coli. Appl Environ Microbiol, 77(3), 871-881. doi:AEM.01901-10 [pii] 10.1128/AEM.01901-10

Flintegaard, T. V., Thygesen, P., Rahbek-Nielsen, H., Levery, S. B., Kristensen, C., Clausen, H., \& Bolt, G. (2010). N-glycosylation increases the circulatory half-life of human growth hormone. Endocrinology, 151(11), 5326-5336. doi:10.1210/en.2010-0574

Guarino, C., \& DeLisa, M. P. (2012). A prokaryote-based cell-free translation system that efficiently synthesizes glycoproteins. Glycobiology, 22(5), 596-601. doi:10.1093/glycob/cwr151

Haltiwanger, R. S., \& Lowe, J. B. (2004). Role of glycosylation in development. Annu Rev Biochem, 73, 491-537. doi:10.1146/annurev.biochem.73.011303.074043

Huang, C., Mohanty, S., \& Banerjee, M. (2010). A novel method of production and biophysical characterization of the catalytic domain of yeast oligosaccharyl transferase. Biochemistry, 49(6), 1115-1126. doi:10.1021/bi902181v

Ihssen, J., Haas, J., Kowarik, M., Wiesli, L., Wacker, M., Schwede, T., \& Thony-Meyer, L. (2015). Increased efficiency of Campylobacter jejuni N-oligosaccharyltransferase PgIB by structureguided engineering. Open Biol, 5(4), 140227. doi:10.1098/rsob.140227 
Ihssen, J., Kowarik, M., Wiesli, L., Reiss, R., Wacker, M., \& Thony-Meyer, L. (2012). Structural insights from random mutagenesis of Campylobacter jejuni oligosaccharyltransferase PgIB. BMC Biotechnol, 12(1), 67. doi:10.1186/1472-6750-12-67

Ilyushin, D. G., Smirnov, I. V., Belogurov, A. A., Jr., Dyachenko, I. A., Zharmukhamedova, T., Novozhilova, T. I., . . Gabibov, A. G. (2013). Chemical polysialylation of human recombinant butyrylcholinesterase delivers a long-acting bioscavenger for nerve agents in vivo. Proc Natl Acad Sci U S A, 110(4), 1243-1248. doi:10.1073/pnas.1211118110

Jervis, A. J., Langdon, R., Hitchen, P., Lawson, A. J., Wood, A., Fothergill, J. L., . . Linton, D. (2010). Characterization of $\mathrm{N}$-linked protein glycosylation in Helicobacter pullorum. $J$ Bacteriol, 192(19), 5228-5236. doi:JB.00211-10 [pii] 10.1128/JB.00211-10

Jewett, M. C., \& Swartz, J. R. (2004). Rapid expression and purification of $100 \mathrm{nmol}$ quantities of active protein using cell-free protein synthesis. Biotechnol Prog, 20(1), 102-109. doi:10.1021/bp0341693

Kowarik, M., Numao, S., Feldman, M. F., Schulz, B. L., Callewaert, N., Kiermaier, E., . . A Aebi, M. (2006). N-linked glycosylation of folded proteins by the bacterial oligosaccharyltransferase. Science, 314(5802), 1148-1150. doi:314/5802/1148 [pii] 10.1126/science.1134351

Kowarik, M., Young, N. M., Numao, S., Schulz, B. L., Hug, I., Callewaert, N., . . Aebi, M. (2006). Definition of the bacterial N-glycosylation site consensus sequence. EMBO J, 25(9), 19571966.

Kwon, Y. C., \& Jewett, M. C. (2015). High-throughput preparation methods of crude extract for robust cell-free protein synthesis. Sci Rep, 5, 8663. doi:10.1038/srep08663

Lau, K. S., \& Dennis, J. W. (2008). N-Glycans in cancer progression. Glycobiology, 18(10), 750-760. doi:10.1093/glycob/cwn071

Li, T., DiLillo, D. J., Bournazos, S., Giddens, J. P., Ravetch, J. V., \& Wang, L. X. (2017). Modulating IgG effector function by Fc glycan engineering. Proc Natl Acad Sci U S A, 114(13), 34853490. doi:10.1073/pnas. 1702173114 
Lin, C. W., Tsai, M. H., Li, S. T., Tsai, T. I., Chu, K. C., Liu, Y. C., . . Wong, C. H. (2015). A common glycan structure on immunoglobulin $\mathrm{G}$ for enhancement of effector functions. Proc Natl Acad Sci U S A, 112(34), 10611-10616. doi:10.1073/pnas.1513456112

Lindhout, T., Iqbal, U., Willis, L. M., Reid, A. N., Li, J., Liu, X., . . Wakarchuk, W. W. (2011). Sitespecific enzymatic polysialylation of therapeutic proteins using bacterial enzymes. Proc Natl Acad Sci U S A, 108(18), 7397-7402. doi:10.1073/pnas.1019266108

Lipinski, T., Fitieh, A., St Pierre, J., Ostergaard, H. L., Bundle, D. R., \& Touret, N. (2013). Enhanced immunogenicity of a tricomponent mannan tetanus toxoid conjugate vaccine targeted to dendritic cells via Dectin-1 by incorporating beta-glucan. J Immunol, 190(8), 4116-4128. doi:10.4049/jimmunol.1202937

Lizak, C., Gerber, S., Numao, S., Aebi, M., \& Locher, K. P. (2011). X-ray structure of a bacterial oligosaccharyltransferase. Nature, 474(7351), 350-355. doi:nature10151 [pii] $10.1038 /$ nature 10151

Mally, M., Fontana, C., Leibundgut-Landmann, S., Laacisse, L., Fan, Y. Y., Widmalm, G., \& Aebi, M. (2013). Glycoengineering of host mimicking type-2 LacNAc polymers and Lewis X antigens on bacterial cell surfaces. Mol Microbiol, 87(1), 112-131. doi:10.1111/mmi.12086

Matsumoto, S., Shimada, A., Nyirenda, J., Igura, M., Kawano, Y., \& Kohda, D. (2013). Crystal structures of an archaeal oligosaccharyltransferase provide insights into the catalytic cycle of N-linked protein glycosylation. Proc Natl Acad Sci U S A, 110(44), 17868-17873. doi:10.1073/pnas.1309777110

Nasab, F. P., Schulz, B. L., Gamarro, F., Parodi, A. J., \& Aebi, M. (2008). All in one: Leishmania major STT3 proteins substitute for the whole oligosaccharyltransferase complex in Saccharomyces cerevisiae. Mol Biol Cell, 19(9), 3758-3768. doi:E08-05-0467 [pii] 10.1091/mbc.E08-05-0467

Nothaft, H., \& Szymanski, C. M. (2010). Protein glycosylation in bacteria: sweeter than ever. Nat Rev Microbiol, 8(11), 765-778. doi:nrmicro2383 [pii] 10.1038/nrmicro2383 
Ollis, A. A., Chai, Y., Natarajan, A., Perregaux, E., Jaroentomeechai, T., Guarino, C., . . DeLisa, M. P. (2015). Substitute sweeteners: diverse bacterial oligosaccharyltransferases with unique N-glycosylation site preferences. Sci Rep, 5, 15237. doi:10.1038/srep15237

Ollis, A. A., Zhang, S., Fisher, A. C., \& DeLisa, M. P. (2014). Engineered oligosaccharyltransferases with greatly relaxed acceptor-site specificity. Nat Chem Biol, 10(10), 816-822. doi:10.1038/nchembio.1609

Pandhal, J., Woodruff, L. B., Jaffe, S., Desai, P., Ow, S. Y., Noirel, J., . . Wright, P. C. (2013). Inverse metabolic engineering to improve Escherichia coli as an N-glycosylation host. Biotechnol Bioeng, 110(9), 2482-2493. doi:10.1002/bit.24920

Pinho, S. S., \& Reis, C. A. (2015). Glycosylation in cancer: mechanisms and clinical implications. Nat Rev Cancer, 15(9), 540-555. doi:10.1038/nrc3982

Rudd, P. M., Elliott, T., Cresswell, P., Wilson, I. A., \& Dwek, R. A. (2001). Glycosylation and the immune system. Science, 291(5512), 2370-2376.

Sadoulet, M. O., Franceschi, C., Aubert, M., Silvy, F., Bernard, J. P., Lombardo, D., \& Mas, E. (2007). Glycoengineering of alphaGal xenoantigen on recombinant peptide bearing the J28 pancreatic oncofetal glycotope. Glycobiology, 17(6), 620-630. doi:10.1093/glycob/cwm028

Schoborg, J. A., Hershewe, J. M., Stark, J. C., Kightlinger, W. K., Kath, J. E., Jaroentomeechai, T., . . Jewett, M. C. (2017). A cell-free platform for rapid synthesis and testing of active oligosaccharyltransferases. bioRxiv. doi: https://doi.org/10.1101/145227

Tytgat, H. L., \& de Vos, W. M. (2016). Sugar Coating the Envelope: Glycoconjugates for MicrobeHost Crosstalk. Trends Microbiol, 24(11), 853-861. doi:10.1016/j.tim.2016.06.004

Valderrama-Rincon, J. D., Fisher, A. C., Merritt, J. H., Fan, Y. Y., Reading, C. A., Chhiba, K., . . DeLisa, M. P. (2012). An engineered eukaryotic protein glycosylation pathway in Escherichia coli. Nat Chem Biol, 8(5), 434-436. doi:10.1038/nchembio.921 
Valguarnera, E., Kinsella, R. L., \& Feldman, M. F. (2016). Sugar and Spice Make Bacteria Not Nice: Protein Glycosylation and Its Influence in Pathogenesis. J Mol Biol, 428(16), 3206-3220. doi:10.1016/j.jmb.2016.04.013

Varki, A. (1993). Biological roles of oligosaccharides: all of the theories are correct. Glycobiology, $3(2), 97-130$.

Wacker, M., Linton, D., Hitchen, P. G., Nita-Lazar, M., Haslam, S. M., North, S. J., . . Aebi, M. (2002). N-linked glycosylation in Campylobacter jejuni and its functional transfer into E. coli. Science, 298(5599), 1790-1793.

Wacker, M., Wang, L., Kowarik, M., Dowd, M., Lipowsky, G., Faridmoayer, A., . . Lee, J. C. (2014). Prevention of Staphylococcus aureus infections by glycoprotein vaccines synthesized in Escherichia coli. J Infect Dis, 209(10), 1551-1561. doi:10.1093/infdis/jit800

Weerapana, E., \& Imperiali, B. (2006). Asparagine-linked protein glycosylation: from eukaryotic to prokaryotic systems. Glycobiology, 16(6), 91R-101R.

Yan, Q., \& Lennarz, W. J. (2002). Studies on the function of oligosaccharyl transferase subunits. Stt3p is directly involved in the glycosylation process. J Biol Chem, 277(49), 47692-47700.

\section{Figure captions}

Figure 1. An integrated pipeline for studying and engineering ssOSTs. (a) Glycocompetent $E$. coli strain carrying YebF acceptor protein and glycan biosynthesis pathway (e.g., pgl locus) is transformed with a combinatorial library of SSOST variants. The library is screened using the glycoSNAP assay, a high-throughput screening methodology using modified colony blotting to generate a genotype-glycophenotype linkage. (b) The isolated variants are then subjected to in vitro production and characterization methods with a goal of developing detailed structure-activity relationships (SARs) for each ssOST. Functional analysis under tightly controlled conditions is performed using IVG with purified protein acceptor, extracted LLOs as the glycan donor, and one of the following: crude membrane extract containing active ssOST enzyme, purified ssOST enzyme, 
or CFPS-derived ssOST supplemented with POPC-nanodiscs. Protein glycosylation is confirmed by SDS-PAGE and immunoblotting with glycan-specific antibody or lectin. The entire process takes only about two weeks and yields a set of SSOST variants with desired traits.

Figure 2. The glycoSNAP screening methodology. Glycocompetent E. coli strain carrying YebF acceptor protein and glycan biosynthesis locus is transformed with a combinatorial library of ssOST variants and plated on agar plate(s). Filter membrane is used to replicate colonies onto induction plate(s) containing inducers for the expression of YebF and NLG pathway enzymes. The glycosylated YebF is secreted out of the cells, after which it is immobilized on overlaid nitrocellulose membranes and detected by subjecting the nitrocellulose membrane to immunoblotting with glycanspecific antibody or lectin. Glycosylation competent (+) and incompetent (-) clones are verified by Western blotting of liquid culture supernatants using anti-His antibodies to detect the acceptor protein and anti-glycan antibodies (or lectins) to detect the oligosaccharide.

Figure 3. Cell-free production and characterization of ssOSTs. (a) Schematic of IVG for in vitro modification of purified acceptor peptides/proteins in the presence of extracted LLOs and sSOSTs that are provided by one of the following methods: crude membrane extraction or purification from cells expressing sSOST enzyme, or CFPS-based expression in the presence of POPC-nanodiscs. (b) Immunoblot analysis of IVG products generated by incubating the following: (1) LLOs, (2) POPC-nanodiscs containing bacterial PglB homologs from C. jejuni (CjPglB), C. coli (CcPglB), C. lari (C/PgIB) and Desulfovibrio gigas (DgPglB), and (3) the acceptor protein scFv13-R4 containing a C-terminal glycosylation tag (GlycTag) encoding either a canonical (scFv13-R4 ${ }^{\text {DQNAT }}$ ) or non-

23 canonical (scFv13-R4 ${ }^{\text {AQNAT }}$ ) sequon. (c) Similar analysis as in (b) using bacterial PglB homologs

24 prepared in crude membrane extracts (top panels). Additional homologs included PglB from C.

25 upsaliensis (CuPg|B), D. desulfuricans (DdPg|B), and D. vulgaris (DvPg|B). IVG of TAMRA-labeled

26 peptides by extracted LLOs and crude membrane extracts containing bacterial PgIB homologs 
1 (bottom panels). IVG-derived products were resolved by tricine/SDS-PAGE, and fluorescence

2 signals were acquired with an image analyzer. (d) Similar analysis as in (b) using purified CjPgIB. In

3 all blots, negative control reactions lacking LLOs (- LLOs) and/or ssOSTs (- OST) were included.

4 Arrows denote aglycosylated $(\mathrm{g} 0)$ and singly glycosylated $(\mathrm{g} 1)$ forms of the scFv13-R4 ${ }^{\text {DQNAT }}$ protein

5 or TAMRA peptides. Blots were probed with antibody against the C-terminal $6 \mathrm{xHis}$ tag (anti-His) on

6 the acceptor protein or anti-glycan serum reactive with C. jejuni heptasaccharide (anti-glycan). 
a

In vivo glycophenotypic screening

glycoSNAP

(glycosylation of secreated $\mathrm{N}$-linked acceptor proteins)

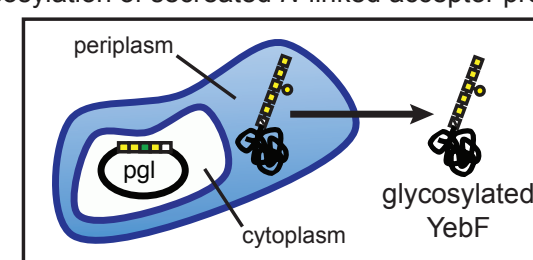

○อㅇำ

library of SSOST variants

glycoSNAP screening

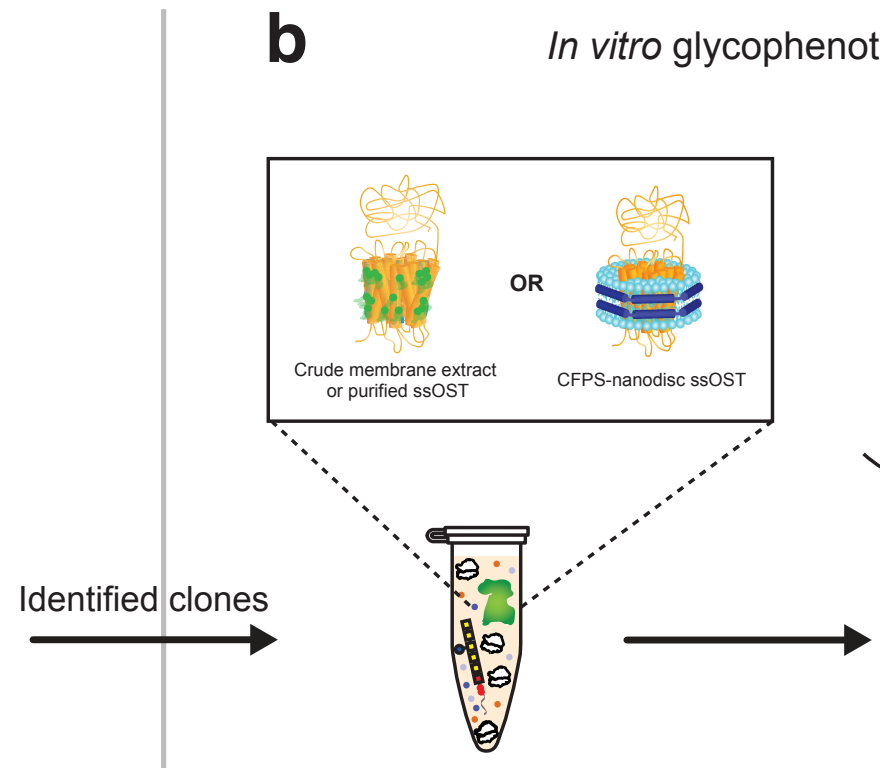

In vitro glycosylation (IVG)

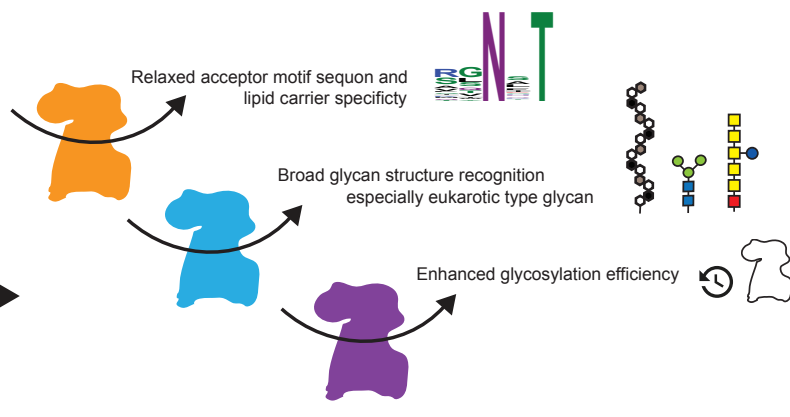

ssOSTs with desired traits

Figure 1 
bioRxiv preprint doi: https://doi org/10.1101/155101; this version posted June 24,2017 . The copyright holder for this preprint (which was not certified by peer review) is the author/funder, who has granted bioRxiv a license to display the preprint in perpetuity. It is made available under aCC-BY-NC 4.0 International license.

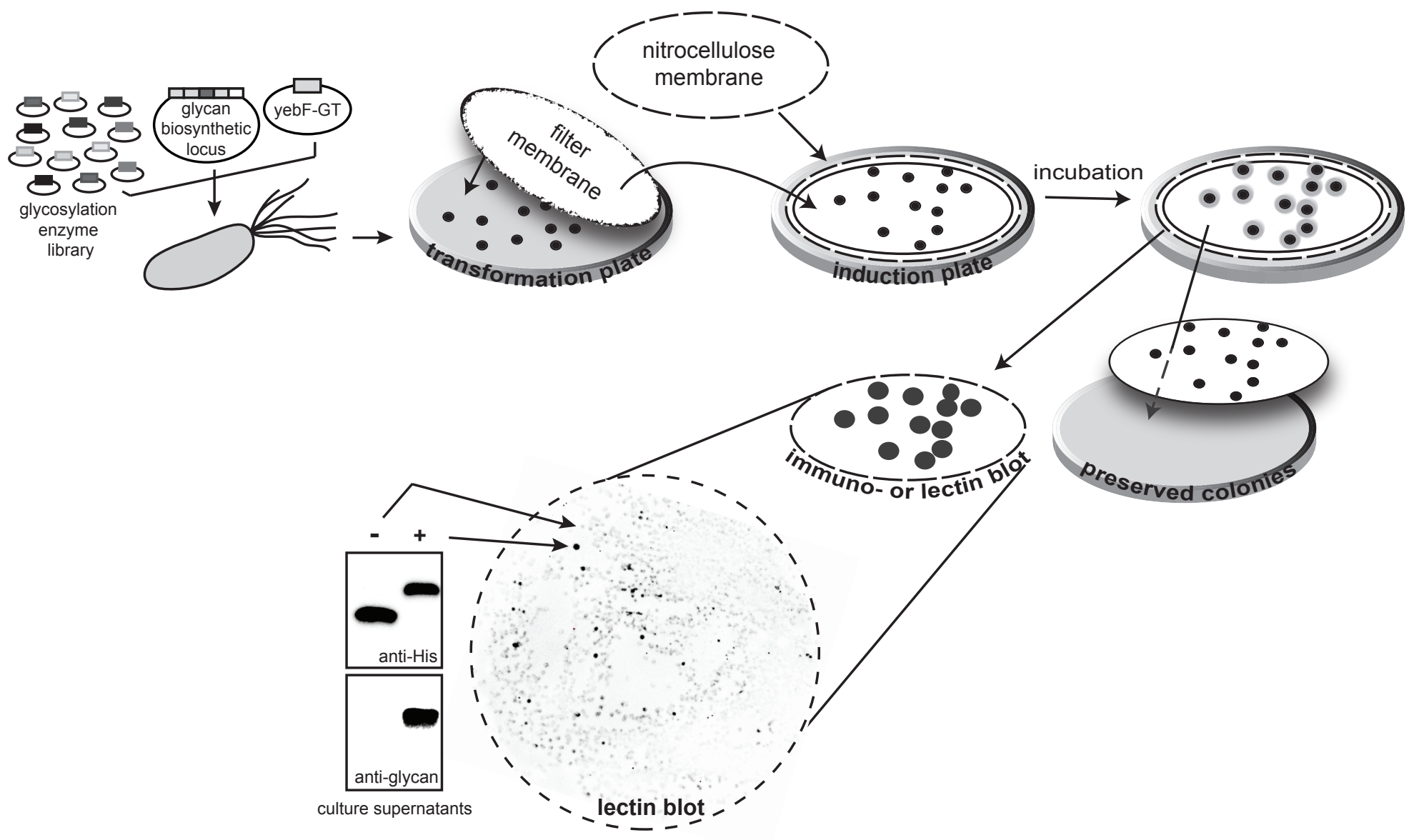


bioRxiv preprint doi: https://doi.org/10.1101/155101· this version posted June 242017 . The copyright holder for this preprint (which was not certified by peer review) is the author/funder, who has granted bioRxiv a license to display the preprint in perpetuity. It is made available under aCC-BY-NC 4.0 International license.

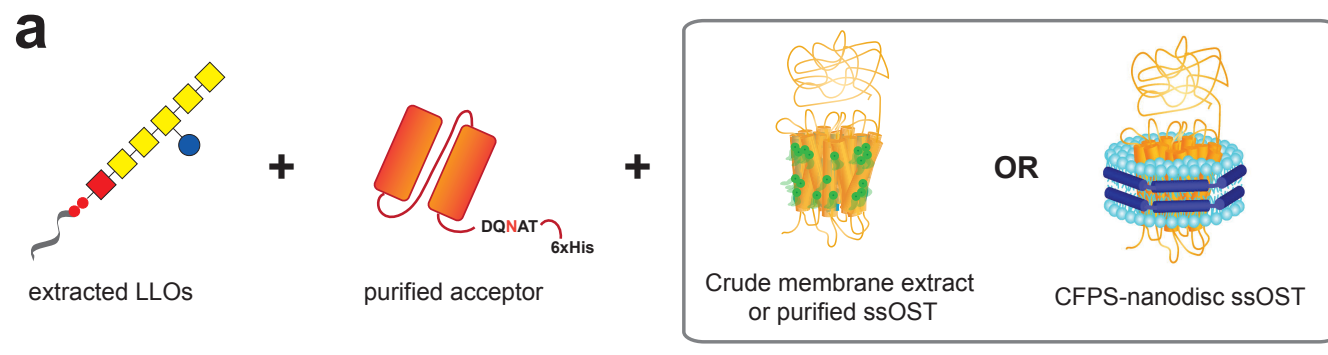

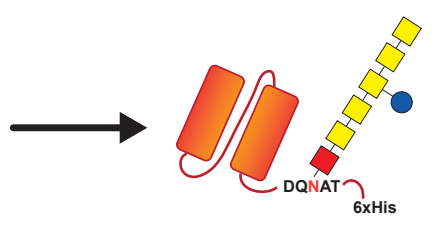

glycoprotein b
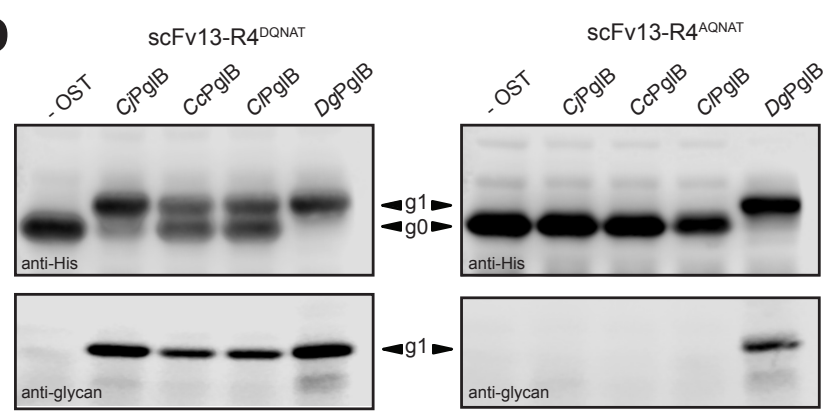

d

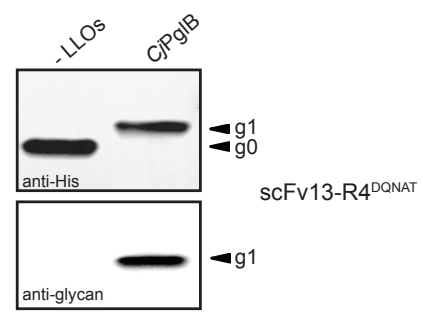

C scFv13-R40 Dant

ScFv13-R4 ${ }^{\text {AQNAT }}$

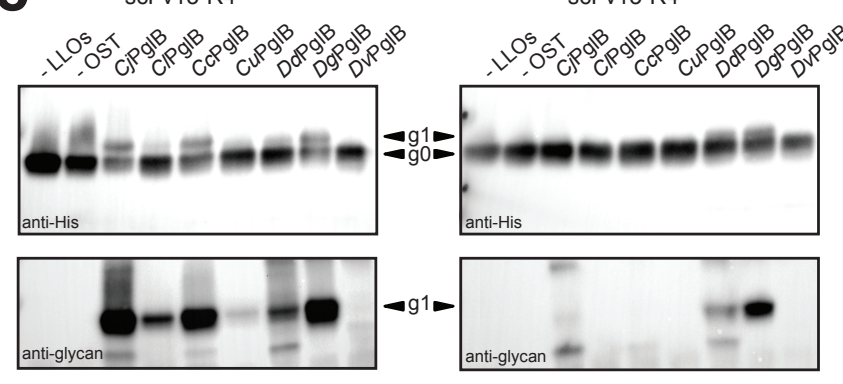

TAMRA-GDQNATAF TAMRA-GAQNATAF

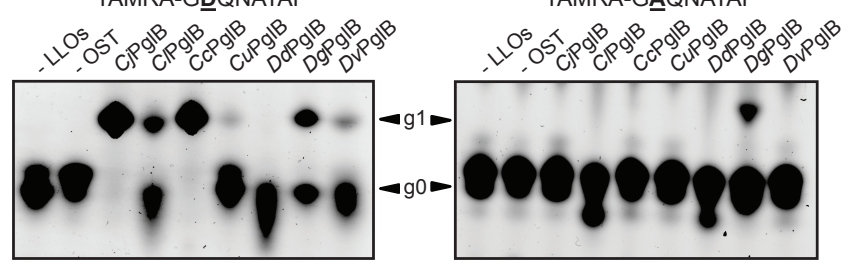

